\title{
TEST ITEM CONSTRUCTION AND ITS APPROPRIATENESS TOWARDS INDICATORS
}

\author{
Jumainah $^{1}$, Muliyadi $^{2}$ \& Norliani $^{3}$
}

1. Program Studi Pendidikan Bahasa Inggris STKIP PGRI Banjarmasin JumaiMainah@gmail.com (081351446515)

2. Program Studi Pendidikan Bahasa Inggris STKIP PGRI Banjarmasin muliyadi_gaffar@yahoo.com (085251589932)

3. Program Studi Pendidikan Bahasa Inggris STKIP PGRI Banjarmasin norliani@stkimbjm.ac.id (082153362552)

\begin{abstract}
Students of Faculty of Teacher Training usually will undergo field experience practice when they are at higher semester, usually at $6^{\text {th }}$ and $7^{\text {th }}$ semester. In their sixth semester they will undergo field experience practice I (PPL I), and at seventh semester, they will undergo field experience practice II (PPL II). In PPL II, they will undergo pre-service teacher training in the form of classroom teaching involvement. They will be given an opportunity to conduct a teaching practice at school where they are assigned. It is worth knowing that although all the students who undergo PPL have been provided with some theoretical knowledges related to teaching and learning process, such as how to teach in class, how to conduct an evaluation, how to construct testitem, etc, yet, they still have experience some problems in the field. One of the most outstanding problems the writers found and has drawn the writer's attention was the test item construction and its appropriateness towards the indicators. The design of this research was descriptive qualitative. The location of the research was the library of STKIP PGRI Banjarmasin, Jl.Sultan Adam Komp. H. Iyus No.18 Rt.23 Banjarmasin. The data source was the document of PPL II report. The document was taken from the students' PPL II report year 2015. The population of the research was the PPL II report of the seventh semester students of English Department of STKIP PGRI Banjarmasin who had taken PPL II and who conducted the PPL II at Senior High school. Since the number of PPL II report consisted of more than 120 RPP reports, then the writers took a sample. The sampling technique used was proportional random sampling. The sample taken was 12 RPP reports which consisted of six reports for middle test and six reports for final test. The result of this research is the test item constructed in PPL II reports mostly inappropriate toward indicators. The inappropriateness (75\%)are mostly caused by no test items provided in RPP.
\end{abstract}

Key Terms: Indicator, Test item, and Lesson plan.

\section{INTRODUCTION}

\section{A. Background}

Students of Faculty of Teacher Training usually will undergo field experience practice when they are at higher semester, usually at $6^{\text {th }}$ and $7^{\text {th }}$ semester. In their sixth semester they will undergo field experience practice I (PPL I), and at seventh semester, they will undergo field experience practice II (PPL II). The difference between PPL I and PPL II are in PPL I students will be assigned to school, either 
junior high school or senior high school, in which they will conduct a week-school observation toward the whole activities conducted at school, such as the teaching and learning process, the administrative activities, the school environment etc. While in PPL II, they will undergo pre-service teacher training in the form of classroom teaching involvement. They will be given an opportunity to conduct a teaching practice at school where they are assigned.

It is worth knowing that although all the students who undergo PPL have been provided with some theoretical knowledge related to teaching and learning process, such as how to teach in class, how to conduct and evaluation, how to construct item test, etc, yet, they still have experience some problems in the field. One of the most outstanding problems the writer found and has drawn the writer's attention was the test item construction and its appropriateness towards the indicators. This reserach was intended to share point of view toward this phenomenon.

\section{B. Problem Formulation}

Test item is constructed based on indicators, and it constitutes basic requirement. This research is intended to find out the appropriateness between test item and indicators. The problem is formulated as follows:

Are the test items constructed in PPL II report of STKIP PGRI Banjarmasin year 2015 appropriatetoward the indicators?

\section{Objective of the Research}

The objective of this research is to find out whether the test item constructed in PPL II report of STKIP PGRI Banjarmasin year 2015 appropriate toward the indicators

\section{Significance of the Research}

1. The students

The students; the students of PPL II must pay attention when they are constructing test item based on the indicators

2. The lecturer

It is as a feedback for lecturers who happen related to the language test construction and its relationship with the indicator.

3. Other researcher

The finding of this research can be used as valuable information for the next researchers who are interested in conducting research on similar object or other objects.

\section{REVIEW OF LITERATURE}

\section{A. The Teaching Device}

The teaching device must be prepared by the teacher before practice the learning. In KBBI (2007: 17), "perangkat adalah alat atau perlengkapan, sedangkan pembelajaran adalah proses atau cara menjadikan orang belajar". The teaching device is the grip for teachers in practice the learning in class, laboratory or outside 
the classroom. In Permendikbud No. 65 Tahun 2013 "tentang Standar Proses Pendidikan Dasar dan Menengah disebutkan bahwa penyusunan perangkat pembelajaran merupakan bagian dari perencanaan pembelajaran". Planning the study was designed in the form of the syllabus and lesson plan which refers to the content standards. In other, that in the planning of learning as well also by the preparation of media and learning resources, the assessment and the scenario of learning. The Unit Level Curriculum of Education (KTSP) is curriculum based competence. Competence is a result of experiences learns together which skills, abilities, and knowledge have interaction to form unity of study related to duty which have been provided. Competence measured precisely in various levels of learning. To estimate the result of lessons be applied to systems of indicators. The explanations used for research have to appropriate and support the understanding with the problem to study. The explanation used to support this research is: lesson plan which it contains formulation of evaluation and indicator.

\section{B. Teaching and Learning Process}

Ideally before entering the class, a teacher must prepare what is called as lesson plan or RPP. Brown (2001:149) stated that "lesson plans is a set of activities that cover a period of class room time, usually ranging from forty to ninety minutes". This lesson plan or RPP indicates the teacher readiness in teaching. Without preparing RPP, the teaching and learning process conducted will undergo some problems as the teacher will teach without knowing where to go-even experienced teachers need this preparation. Due to that, the preparation needs to be conducted in the form of Lesson plan or RPP. Lesson plan or RPP constitutes a written preparation conducted by a teacher before entering the class. Based on this written preparation, the teacher will conduct the teaching and learning process.

\section{Teaching Preparation}

As discussed previously that RPP constitutes written preparation the teacher makes before entering the class. This needs to be made in order the teaching and learning process can run well. The general description of the teaching and learning process is described by the following figure:

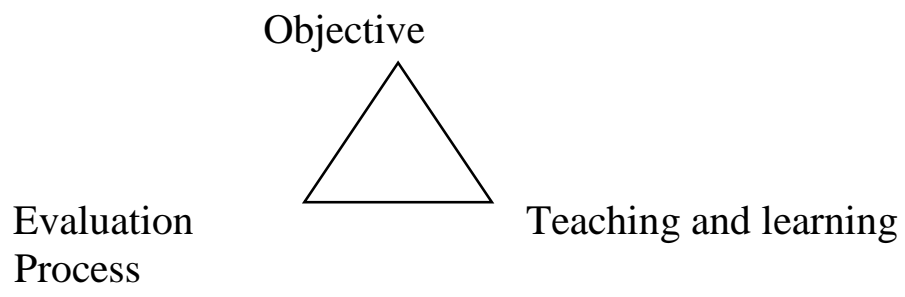

Figure 1: Teaching and learning process

The figure above describes that before the teacher entering the class, he/she has to set objectives first. Then, after setting up the objectives, he/she conducts the teaching and learning process. At the end of the teaching and learning process, he/she will conduct what is called as an evaluation. An evaluation is intended to measure the effectiveness or the successfulness theteaching and learning process conducted, 
whether the objectives set have been achieved or not, etc. Based on the result of this evaluation, the teacher may acquire a feedback whether to proceed to teaching the next material or conducting some remedial teaching toward some students or even the whole class who happen fail to achieve KKM.The relationship among the components is best described by completing the above figure with some arrows that show the relationship.

Evaluation

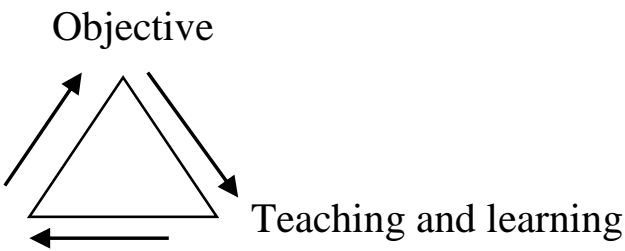

Process

Figure 2: The desription of how the three components of teaching and learning process interrelated

\section{Evaluation}

According to Hamalik, (In Martinis 2008:194) "evaluation is the whole activity measured (data retrieval and information), interpretation, and considered to make a decision about the level of the result students' with learning activities in an effort to achieve the purpose of learning that has been set".

A similar opinion on that case, Muslich (2008:107) stated that "Evaluasi merupakan serangkaian kegiatan untuk memperoleh, menganalisis, dan menafsirkan data tentang proses dan hasil belajar peserta didik yang dilakukan secara sistematis dan berkesinambungan sehingga menjadi informasi yang bermakna dalam pengambilan keputusan".

An evaluation is the last part conducted in teaching and learning process. An evaluation is the systematic process of collecting and analyzing data to know whether the objective of learning being achieved or not. Collection of data to determine degree of achievement of objectives requires administration of one or more instruments. Such instruments must either be developed or selected. Selection of an instrument involves examining those that are available and selecting the best one. Best, in this case, means the one that is most appropriate for your objectives and users. Development of a good instrument takes considerable time, effort and skill. That's why in the filed frequently found inappropriateness between indicators and the test made.Its description can be seen from the following components of RPP as it is formatted by Permendiknas nomor 41 tahun 2007 for KTSP and Permendiknas nomor 103 tahun 2014 for K-13. The components for KTSP consist of identitas mata pelajaran, standar kompetensi, kompetensi dasar, indicator pencapaian kompetensi, tujuan pembelajaran, materi ajar, alokasi waktu, metode pembelajaran, penilaian hasil belajar, sumber belajar while the components for K-13 consist of Kompetensi Inti, Kompetensi Dasar, Indikator pencapaian kompetensi, Materi pembelajaran, Kegiatan pembelajaran, Penilaian hasil belajar, Media, Bahan dan sumber belajar. 
From the above components, there two main parts the writer considered very important related to an evaluation conducted. The two main parts are (1) Indicators, and (2) Evaluation. These two components are interrelated one to another. The indicators are generated based on the basic competence. Based on the indicators, the teacher construct test items as an insrument used for an evaluation. However, the test items contrution arises some problems. One of the problems is the test made is inappropriate towardthe indicators set.

\section{E. Test Item Appropriateness toward Indicators}

To conduct an evaluation, there are several ways that can be used, such as written test or oral test, performance assessment, attitude assessment, product assessment, portfolios, and self assessment. In term of written test, test items are basically constructed based on indicators set. "...pembuatan indikator lebih banyak untuk kepentingan proses penilaian dan pengukuran" (Sugeng, dkk.,37). Indicator is a term used to refer to the ability of the students to achieve the basic competency. According to Muslich (2008:33) "Penjabaran dari kompetensi dasar yang menunjukkan tandatanda, perbuatan, dan respon yang dilakukan atau ditampilkan oleh peserta didik disebut indikator", Mulyasa (2007:139) said the same opinion with Muchlish's opinion "indikator kompetensi adalah perilaku yang dapat diukur dan atau diobservasi untuk menunjukkan ketercapaian kompetensi dasar tertentu yang menjadi acuan penilaian mata pelajaran". This Indicator is used as a guideline by the teacher to construct the test items.

Based on the field practice report, most of the field practice report containing test items are not well constructed as it is not in agreement with the indicators set. In the mean time, it is stated that the test items constructed must be made in agreement with the indicators. The following are some examples of the deviances of test items construction toward the indicators set.

\begin{tabular}{|l|l|}
\hline Indicators and simple & Test items \\
\hline $\begin{array}{l}\text { perform short and short dialogue of how to use } \\
\text { conversation fluently using the } \\
\text { expressions, such as good morning, } \\
\text { good afternoon, how are you today, } \\
\text { etc. }\end{array}$ & $\begin{array}{l}\text { Makpessions if you meet someone } \\
\text { based on condition and time provided. }\end{array}$ \\
\hline $\begin{array}{l}\text { discriminate present tense and } \\
\text { present continuous tense }\end{array}$ & $\begin{array}{l}\text { She is reading a book } \\
\text { a. present tense } \\
\text { b. present continuous }\end{array}$ \\
\hline $\begin{array}{l}\text { identify negative sentences of } \\
\text { simple present tense }\end{array}$ & $\begin{array}{l}\text { Give example of negative sentences } \\
\text { in the form of simple present tense. }\end{array}$ \\
\hline
\end{tabular}

The first example of inappropriateness of indicator towards the test item is best described by the words "perform" and "make short dialogue." While the second 
example is the word "to identify" as found in indicator is not in agreement with the test item as in test item the students are not provided with two tenses present tense, and present continuous. They are provided with single sentence of present continuous which means they are not discriminating, but identifying. And the last one, is the use of the word "simple present tense" while the test item the students are asked to give example instead of identifying. The following are some examples that show how thinking levels (which refer to action words used in indicators) relate to the test items constructed:

\section{$\underline{\text { Thinking level } \quad \text { What students do }}$}

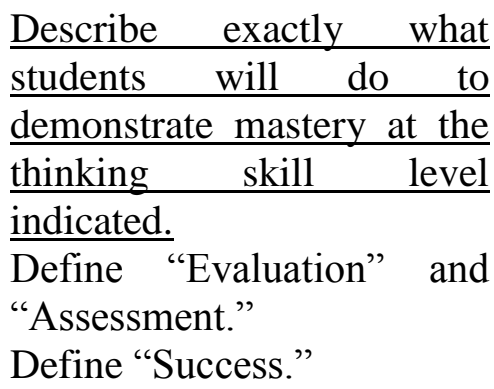

Comprehension

Application

Analysis

Synthesis

Evaluation
Name, describe, select, define, match, state, etc.
Define "Success."

Provide examples of three simple present tense Summarize, explain, provide Solve problems, construct charts, demonstrate usage.

Divide, distinguish categorize, infer, separate.

Combine, revise, organize, create new perspective.

Judge, prioritize, value, evaluate, conclude, design approach
Construct a chart of critical success factors applicable to learning at school.

Distinguish between simple present tense and simple past.

Organize the following jumbled sentences to form a good paragraph.

Conclude the moral value based on the story you read

It is worth knowing that according to Isdisusilo (2012'29) states that indicator is

- behavioural characteristics (measurable evidence) that cangive an idea that the learners have achieved basic competence

- achievement markers ofbasic competence which is characterized by behavioural changes that can be measured which includes attitudes, knowledge, and skills

- formulation of indicator uses operational word which is measurable and/or observable

- used as a basis to draw up an assessment too

From several points above,the last point shows that the indicators are the basic foundation or guidance for a teacher in making the test questions. Thus, when a teacher makes test questions without referring to the indicator, then the question that 
he makes is plain wrong. So, it is important to ascertain that test makes reflect the relevance or suitability to the indicators set

\section{A. Indicator Functions}

Indicator as part of the RPP component has a very important role in order to achieve competence. This is because the indicators have multiple functions. The functions of indicator according Isdisusilo (2012 160 161) are:

- Guidance in developing learning materials

The development of learning materials must be in accordance with the indicators developed. Indicators are carefully formulated to provide direction in the development of effective learning materials according to the characteristics of the subjects, the potential and needs of the students, the school and the environment

- The guidance in designing learning activities

Instructional design needs to be designed effectively to competency can be achieved to the fullest. Development of instructional design should be in accordance with the indicators developed, since indicators to provide an overview of effective learning activities to achieve competence. Indicators are demanding competence dominant on the procedural aspects of the learning activities carried out shows that the strategy is not expository but more precise strategy discovery-inquiry

- Guidance in developing teaching materials

Teaching materials need to be developed by teachers in order to support the achievement of competence of learners. Selection of effective teaching materials must fit the demands of indicators so as to improve the achievement of competencies to the fullest.

- Guidelines in designing and implementing learning outcomes assessment Indicators guide you in designing, implementing, and evaluating learning outcomes. The draft assessment provides guidance in determining the shape and type of assessment, and the development of assessment indicators. Developing indicators assessment should be based on achievement indicators developed in accordance with SK and KD.

\section{METHODOLOGY}

The design of this study is descriptive qualitative, that is to describe about the appropriateness between test items and the indicators in students' PPL II report year 2015. The location of the research is the library of STKIP PGRI Banjarmasin, Jl. Sultan Adam Komp. H. Iyus No.18 Rt.23 Banjarmasin. The data collection technique uses documentation. The documentation is taken from the students' PPL II report year 2015.

The population of the research is the PPL II report of the seventh semester students of English Department of STKIP PGRI Banjarmasin who had taken PPL II and who conducted the PPL II at Senior High school. The number of the school is 15 schools that consist of 4 students for every school. While the total number of PPL II report from those schools consist of 60 PPL II report. Each report consists of two 
RPP that is, RPP for middle test and RPP for final test. Thus the number of population $120 \mathrm{RPP}$ reports.

Since the number of PPL II report consists of more than 120 RPP reports, then the researchers take a sample. The researchers use proportional random sampling. The sample taken is 12 RPP reports which consist of six reports for middle test and six reports for final test. It is in accordance with Arikunto (2010:112), that states "apabila subjeknya kurang dari 100,lebih baik diambil semua sehingga penelitiannya merupakan penelitian populasi"Selanjutnya, jika jumlah subjeknya besar dapat diambil antara 10-15\% atau 20-25\% atau lebih". Thus, the researchers take $10 \%$ from the population as a research sample. The data obtained through documentation were analyzed qualitatively. It is conducted by analyzing the test item whether it is in accordance with the indicators or not.

The researchers analyze the data arranged into some particular steps; the first is selecting the instrument. It is used to make the analysis easier, clearer, and more focus. There are two research instruments, namely research instrument of indicator, and research instrument of evaluations. Second is collecting and analyzing of the data. In the step, the data is started to collect and analyze by using research instrument. Third is interpretation of the result.

\section{FINDINGS AND DISCUSSION}

\section{A. Findings}

Appropriateness of indictors with the test item is required in determining success the learning process which carried out, appropriateness could be observed from the lesson plans that was made before the learning going on. Hopefully the PPL II students can optimally arrange the lesson plans as a proof that they have mastered the theory and practice as well.The finding is presented in the form of descriptive analysis of appropriateness between test items and the indicators constructed in students' PPL II report of STKIP PGRI Banjarmasin.

Table 1. The result of analysis of appropriateness between test items and the indicators constructed in students' PPL II report of STKIP PGRI Banjarmasin

\begin{tabular}{|c|c|c|c|c|c|}
\hline \multirow{2}{*}{$\begin{array}{l}\text { Number } \\
\text { of data } \\
\text { source } \\
\text { (middle } \\
\text { test) }\end{array}$} & \multirow[b]{2}{*}{ Indicators } & \multirow[b]{2}{*}{ Subjects } & \multirow[b]{2}{*}{ Test Items } & \multicolumn{2}{|c|}{$\begin{array}{l}\text { Appropriate } \\
\text { ness }\end{array}$} \\
\hline & & & & Yes & No \\
\hline 1 & $\begin{array}{ll}\text { 1. } & \text { Menyampaikan } \\
\text { laporan tentang apa } \\
\text { yang diamati } \\
\text { 2. } & \text { Menjawab } \\
\text { pertanyaan } \\
\text { mengenai suatu } \\
\text { gambar }\end{array}$ & $\begin{array}{l}\text { Definisi report text } \\
\text { Generic structure: } \\
\text { 1. General } \\
\quad \text { classification } \\
\text { 2. Description1 } \\
\text { Grammar: } \\
\text { - simple present tense } \\
\text { - Action verbs (run, } \\
\text { eat, sleep, etc) } \\
\text { - Verbs (is/are, } \\
\text { have/has) }\end{array}$ & 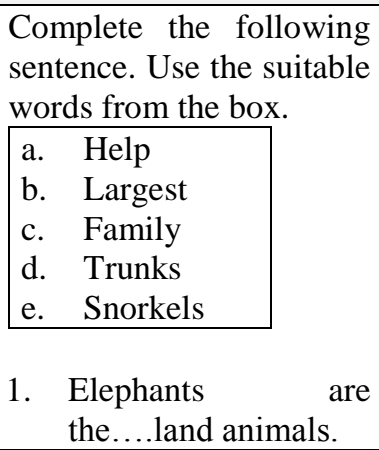 & & $\sqrt{ }$ \\
\hline
\end{tabular}


Test Item Construction and Its Appropriateness

Towards Indicators

\begin{tabular}{|c|c|c|c|c|c|}
\hline & & & 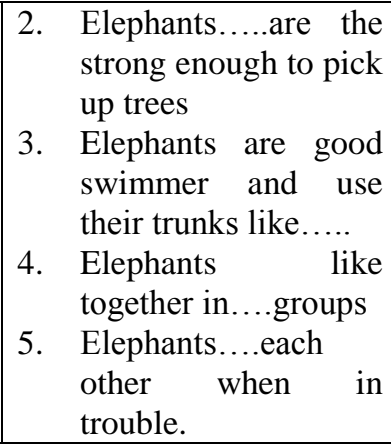 & & \\
\hline 2 & $\begin{array}{l}\text { 1. Mengidentifikasi } \\
\text { makna teks } \\
\text { fungsional } \\
\text { berbentuk } \\
\text { peringatan (caution) } \\
\text { 2. Menentukan tujuan } \\
\text { komunikasi dari } \\
\text { Caution }\end{array}$ & $\begin{array}{l}\text { Definisi caution } \\
\text { Example } \\
\text { Unsur kebahasaan: } \\
\text { - Kata dan bahasa } \\
\text { yang lazim } \\
\text { digunakan } \\
\text { - Ejaan yang jelas } \\
\text { - Ucapan, tekanan } \\
\text { kata, intonasi } \\
\text { ketika } \\
\text { mempresentasika } \\
\text { n secara lisan } \\
\text { Topic: } \\
\text { lingkungan } \\
\text { sekolah dan } \\
\text { tempat umum } \\
\text { (jalanraya, } \\
\text { rumahsakit, } \\
\text { perpustakaan dsb) }\end{array}$ & & & $\sqrt{ }$ \\
\hline 3 & $\begin{array}{l}\text { 1. Write the notices } \\
\text { based on the clues } \\
\text { given }\end{array}$ & $\begin{array}{l}\text { Definisi Notices } \\
\text { Contoh Notices } \\
\text { Fungsi Notices }\end{array}$ & a. & & $\sqrt{ }$ \\
\hline 4 & $\begin{array}{l}\text { 1. } \text { Mengidentifikasi } \\
\text { topic sebuah teks } \\
\text { fungsional pendek } \\
\text { yang didengar } \\
\text { 2. Menggunakan tata } \\
\text { bahasa, kosa kata, } \\
\text { tanda baca, ejaan } \\
\text { dan tata tulis } \\
\text { dengan akurat }\end{array}$ & $\begin{array}{l}\text { Topic : letter } \\
\text { Utterances: do you } \\
\text { know what is the } \\
\text { functional of letter? } \\
\text { Do you know what } \\
\text { the criteria to make a } \\
\text { good letter are? } \\
\text { Interrogative words: } \\
\text { what, who, how, etc } \\
\text { Pronouns: I, she, he, } \\
\text { it, your, my, his, her } \\
\text { Article: a, an, the }\end{array}$ & & & $\sqrt{ }$ \\
\hline 5 & 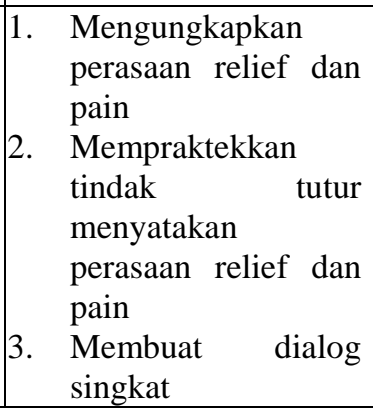 & $\begin{array}{l}\text { - Definitions of relief } \\
\text { and pain } \\
\text { - Expressions of } \\
\text { relief, ex; I am so } \\
\text { relief to hear that } \\
\text { - expressions of pain, } \\
\text { ex:I feel ill } \\
\text { Examples of } \\
\text { expressing relief } \\
\text { and pain in dialog }\end{array}$ & $\begin{array}{l}\text { Soal: } \\
\text { Make a short dialog using } \\
\text { the expression of relief } \\
\text { and pain! } \\
\text { a. Some boys are in the } \\
\text { school yard playing } \\
\text { football. When a girl } \\
\text { passes the field, the } \\
\text { ball hit her } \\
\text { You see your friend }\end{array}$ & $\sqrt{ }$ & \\
\hline
\end{tabular}




\begin{tabular}{|c|c|c|c|c|c|}
\hline & $\begin{array}{l}\text { menggunakan } \\
\text { ekspresi relief dan } \\
\text { pain berdasarkan } \\
\text { situasi yang telah di } \\
\text { berikan }\end{array}$ & & $\begin{array}{l}\text { walking in the slippery } \\
\text { street. You try to warm } \\
\text { him, but you are late and } \\
\text { he fell down }\end{array}$ & & \\
\hline 6 & 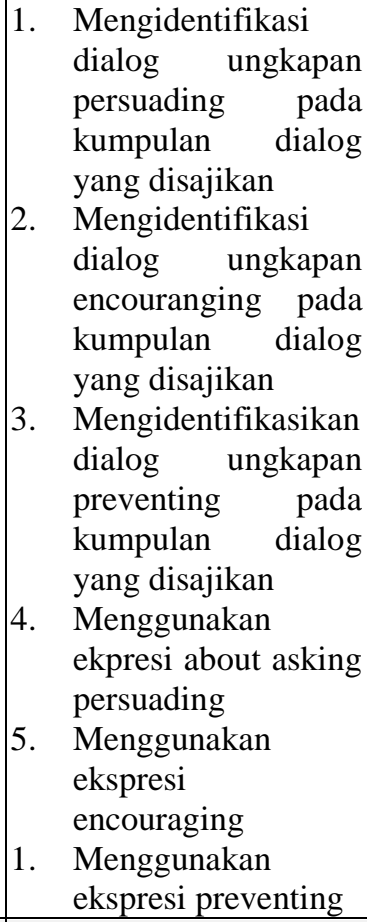 & $\begin{array}{l}\text { 1. } \begin{array}{l}\text { Definition of } \\
\text { persuading, } \\
\text { encouraging, } \\
\text { preventing }\end{array} \\
\text { 2. } \begin{array}{l}\text { Expressing of } \\
\text { persuading, } \\
\text { encouraging,preve } \\
\text { nting }\end{array}\end{array}$ & & & $\sqrt{ }$ \\
\hline \multirow{2}{*}{$\begin{array}{l}\text { Number } \\
\text { of data } \\
\text { source } \\
\text { (final } \\
\text { test) }\end{array}$} & \multirow[b]{2}{*}{ Indicators } & \multirow[b]{2}{*}{ Subjects } & \multirow[b]{2}{*}{ Test Items } & \multicolumn{2}{|c|}{$\begin{array}{l}\text { Appropriate } \\
\text { ness }\end{array}$} \\
\hline & & & & Yes & $\begin{array}{l}\mathrm{N} \\
\mathrm{O}\end{array}$ \\
\hline 1 & $\begin{array}{l}\text { Nama-nama benda dan } \\
\text { kata yang } \\
\text { mendeskripsikan benda } \\
\text { yang terkait dengan } \\
\text { jumlah dan kualitas } \\
\text { disebutkan dengan tepat }\end{array}$ & $\begin{array}{l}\text { Materi kata-kata } \\
\text { bendatunggaldanjama } \\
\mathrm{k}\end{array}$ & $\begin{array}{l}\text { The given nouns are all in } \\
\text { their plural forms. Write } \\
\text { them in their singular } \\
\text { forms. } \\
\text { 1. Roses } \\
\text { 2. Boys } \\
\text { 3. Families } \\
\text { 4. Potatoes } \\
\text { 5. Wives } \\
\text { 6. Photos } \\
\text { 7. Children } \\
\text { 8. Sandwiches } \\
\text { 9. Fish } \\
\text { 10. Feet } \\
\text { 11. Boxes } \\
\text { 12. Ladies } \\
\text { 13. Men } \\
\text { 14. Sheriffs } \\
\text { 15. Shelves } \\
\text { 16. Heroes } \\
\text { 17. Oxen } \\
\text { 18. Diagnoses } \\
\text { 19. Criterion } \\
\text { 20. days }\end{array}$ & $\sqrt{ }$ & \\
\hline
\end{tabular}




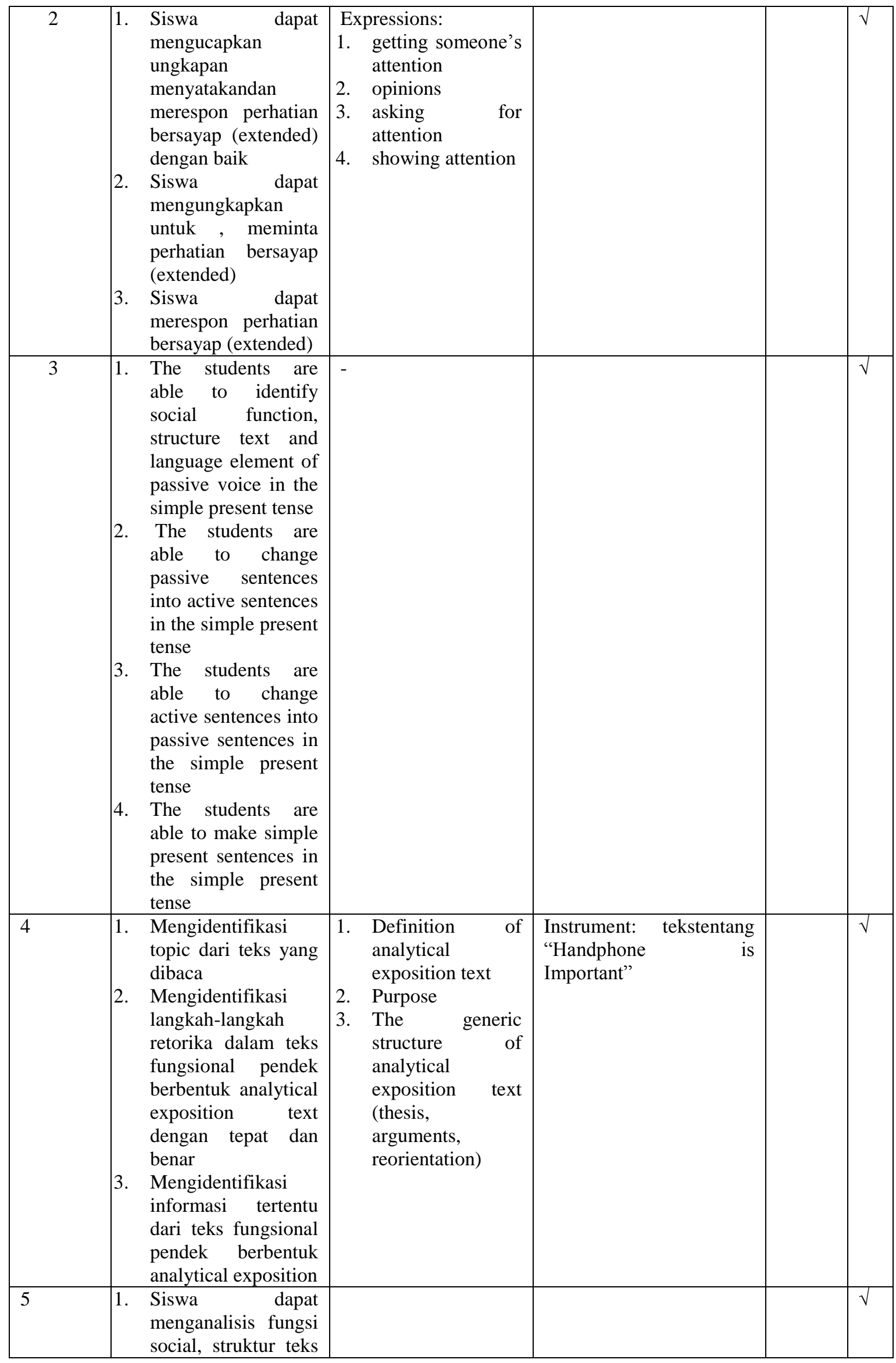




\begin{tabular}{|c|c|c|c|c|}
\hline & 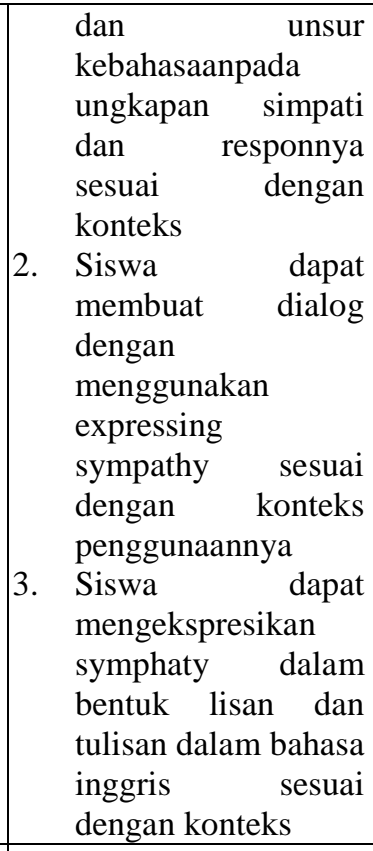 & & & \\
\hline 6 & $\begin{array}{l}\text { 1. } \begin{array}{l}\text { Reading loudly the } \\
\text { text }\end{array} \\
\text { 2. } \begin{array}{l}\text { Identifying the } \\
\text { generic structure of }\end{array} \\
\text { the text } \\
\text { 3. } \begin{array}{l}\text { Identifying the } \\
\text { information of the } \\
\text { text }\end{array}\end{array}$ & $\begin{array}{l}\text { 1. } \begin{array}{l}\text { Definition of } \\
\text { narrative }\end{array} \\
\text { 2. The purpose of } \\
\text { narrative } \\
\text { 3. Generic structure } \\
\text { of narrative } \\
\text { 4. Language features } \\
\text { 5. Types of narrative } \\
\text { text }\end{array}$ & $\begin{array}{l}\text { Soal : } \\
\text { Read this text (Malin } \\
\text { Kundang) carefully then } \\
\text { identify the generic } \\
\text { structure of the text! }\end{array}$ & $\sqrt{ }$ \\
\hline
\end{tabular}

Based on the data result analysis above, it can be seen that there is only 1 test items which appropriate with the indicators and there are 5 test items which inappropriate with the indicators in RPP reports for middle test, and there are 2 test items which appropriateness with the indicators and there are 4 test items which not appropriateness with the indicators in RPP reports for final test.

Table 2. The percentage of each report of the appropriateness test item with indicators

\begin{tabular}{|c|c|c|}
\hline No. & Description & Total (\%) \\
\hline 1 & the test item which appropriate with indicators in RPP \\
reports for middle test & $16,7 \%$ \\
\hline 2 & the test item which not appropriate with indicators in RPP \\
reports for middle test & $83,3 \%$ \\
\hline 3 & the test item which inappropriate with indicators in RPP \\
reports for final test & $33,4 \%$ \\
\hline 4 & $\begin{array}{c}\text { the test item which not appropriate with indicators in RPP } \\
\text { reports for final test }\end{array}$ & $66,6 \%$ \\
\hline
\end{tabular}

Table 3. The total number of percentage of the appropriateness test item with indicators

\begin{tabular}{|c|c|c|}
\hline No. & Description & Total (\%) \\
\hline 1 & the test item which appropriate with indicators & $25 \%$ \\
\hline 2 & the test item which inappropriate with indicators & $75 \%$ \\
\hline
\end{tabular}


From the table of percentage above, it can be seen clearly that there are 25 $\%$ from the number of evaluations which appropriate with the indicators, that is 4 test items and $75 \%$ from the number of evaluations which not appropriate with the indicators, 8 test items.

\section{B. Discussion}

Here the researchers will present the test items which appropriate and not appropriate with the indicators.

\section{- The test item which appropriate with the Indicator}

Data source 1

- The indicators

Mengungkapkan perasaan relief dan pain

Mempraktekkan tindak tutur menyatakan perasaam relief dan pain

Membuat dialog singkat menggunakan ekspresi relief dan pain berdasarkan situasi yang telah di berikan

- $\quad$ The test items

Make a short dialog using the expression of relief and pain!

Some boys are in the school yard playing football. When a girl passes the field, the ball hit her

You see your friend walking in the slippery street. You try to warm him, but you are late and he fell down

The Indicator and test item are appropriate because the indicator is Mengungkapkan perasaan relief dan pain, Mempraktekkan tindak tutur menyatakan perasaam relief dan pain, Membuat dialog singkat menggunakan ekspresi relief dan pain berdasarkan situasi yang telah di berikan. While the test item is make a short dialog using the expression of relief and pain!

Data source 2

- The indicators

Reading loudly the text

Identifying the generic structure of the text

Identifying the information of the text

- $\quad$ The test items

Read this text (Malin Kundang) carefully then identify the generic structure of the text!

The Indicator and test item are appropriate because the indicator is Reading loudly the text, Identifying the generic structure of the text, Identifying the information of the text, while the test item is Make a short dialog using the expression of relief and pain!. While the test item is Read this text (Malin Kundang) carefully then identify the generic structure of the text!

Data source 3

- The indicators

Nama-nama benda dan kata yang mendeskripsikan benda yang terkait dengan jumlah dan kualitas disebutkan dengan tepat.

- The test item

The given nouns are all in their plural forms. Write them in their singular forms.
a. Roses
k. Boxes
b. Boys
1. Ladies 

c. Families
m. Men
d. Potatoes
n. Sheriffs
e. Wives
o. shelves
f. Photos
p. heroes
g. Children
q. oxen
h. Sandwiches
r. diagnoses
i. Fish
s. criterion
j. Feet
t. day

The Indicator and test item are appropriate because the indicator is Namanama benda dan kata yang mendeskripsikan benda yang terkait dengan jumlah dan kualitas disebutkan dengan tepat. While the test item is Make a short dialog using the expression of relief and pain!. While the test item is the given nouns are all in their plural forms. Write them in their singular forms.

\section{-The test item which not appropriate with Indicator}

Based on the result of analysis done in PPL II report year 2015, the inappropriateness between test items and indicators will be presented as bellows:

Data Source 1.

- The indicator

Menyampaikan laporan tentang apa yang diamati dan Menjawab pertanyaan mengenai suatu gambar

- The test item

Complete the following sentence. Use the suitable words from the box.

\begin{tabular}{|ll|}
\hline f. & Help \\
g. & Largest \\
h. & Family \\
i. & Trunks \\
j. & Snorkels \\
\hline
\end{tabular}

a. Elephants are the....land animals.

b. Elephants......are the strong enough to pick up trees

c. Elephants are good swimmer and use their trunks like.....

d. Elephants like together in....groups

e. Elephants....each other when in trouble.

The Indicator and test item are inappropriate because the indicators are Menyampaikan laporan tentang apa yang diamati and menjawab pertanyaan mengenai suatu gambar, while the test item is complete the following sentence. Use the suitable words from the box(siswa diminta melengkapi kalimat dengan pilihan kata yang disediakan)

Data source 2.

- The indicators

Mengidentifikasi makna teks fungsional berbentuk peringatan (caution) Menentukan tujuan komunikasi dari Caution

- The test items 
There is no test item

The Indicator and test item are inappropriate because there is no test item that provided, while the indicator is Mengidentifikasi makna teks fungsional berbentuk peringatan (caution) Menentukan tujuan komunikasi dari Caution

Data source 3.

- The indicators

Write the notices based on the clues given

- $\quad$ The test items

There is no test item

The Indicator and test item are inappropriate because there is no test item that provided, while the indicator is Write the notices based on the clues given

Data source 4

- The indicators

1. Mengidentifikasi topic sebuah teks fungsional pendek yang didengar

2. Menggunakan tata bahasa, kosa kata, tanda baca, ejaan dan tata tulis dengan akurat

- The test items

There is no test item

The Indicator and test item are inappropriate because there is no test item that provided, while the indicator is Mengidentifikasi topic sebuah teks fungsional pendek yang didengar and Menggunakan tata bahasa, kosa kata, tanda baca, ejaan dan tata tulis dengan akurat

Data source 5

- The indicators

1. Siswa dapat mengucapkan ungkapan menyatakan dan merespon perhatian bersayap (extended) dengan baik

2. Siswa dapat mengungkapkan untuk, meminta perhatian bersayap (extended)

3. Siswa dapat merespon perhatian bersayap (extended)

- $\quad$ The test items

There is no test item

The Indicator and test item are inappropriate because there is no test item that provided, while the indicator is Siswa dapat mengucapkan ungkapan menyatakan dan merespon perhatian bersayap (extended) dengan baik, Siswa dapat mengungkapkan untuk, meminta perhatian bersayap (extended), Siswa dapat merespon perhatian bersayap (extended)

Data source 6

- The indicators

a. The students are able to identify social function, structure text and language element of passive voice in the simple present tense

b. The students are able to change passive sentences into active sentences in the simple present tense

c. The students are able to change active sentences into passive sentences in the simple present tense

d. The students are able to make simple present sentences in the simple present tense

- $\quad$ The test items 
There is no test item

The Indicator and test item are inappropriate because there is no test item that provided, while the indicator is The students are able to identify social function, structure text and language element of passive voice in the simple present tense, The students are able to change passive sentences into active sentences in the simple present tense, The students are able to change active sentences into passive sentences in the simple present tense, The students are able to make simple present sentences in the simple present tense

Data source 7

- The indicators

a. Mengidentifikasi topic dari teks yang dibaca

b. Mengidentifikasi langkah-langkah retorika dalam teks fungsional pendek berbentuk analytical exposition text dengan tepat dan benar

c. Mengidentifikasi informasi tertentu dari teks fungsional pendek berbentuk analytical exposition

- The test items

There is no test item

The Indicator and test item are inappropriate because there is no test item that provided, while the indicator is Mengidentifikasi topic dari teks yang dibaca, Mengidentifikasi langkah-langkah retorika dalam teks fungsional pendek berbentuk analytical exposition text dengan tepat dan benar, Mengidentifikasi informasi tertentu dari teks fungsional pendek berbentuk analytical exposition

Data source 8

- The indicators

a. Siswa dapat menganalisis fungsi social, struktur teks dan unsure kebahasaan pada ungkapan simpati dan responnya sesuai dengan konteks

b. Siswa dapat membuat dialog dengan menggunakan expressing sympathy sesuai dengan konteks penggunaannya

c. Siswa dapat mengekspresikan symphaty dalam bentuk lisan dan tulisan dalam bahasa inggris sesuai dengan konteks.

- $\quad$ There is no test item

The Indicator and test item are inappropriate because there is no test item that provided, while the indicator is siswa dapat menganalisis fungsi social, struktur teks dan unsur kebahasaan pada ungkapan simpati dan responnya sesuai dengan konteks, Siswa dapat membuat dialog dengan menggunakan expressing sympathy sesuai dengan konteks penggunaannya, Siswa dapat mengekspresikan symphaty dalam bentuk lisan dan tulisan dalam bahasa inggris sesuai dengan konteks

Data source 9

- The indicators

a. Mengidentifikasi dialog ungkapan persuading pada kumpulan dialog yang disajikan

b. Mengidentifikasi dialog ungkapan encouranging pada kumpulan dialog yang disajikan

c. Mengidentifikasikan dialog ungkapan preventing pada kumpulan dialog yang disajikan

d. Menggunakan ekpresi about asking persuading

e. Menggunakan ekspresi encouraging 


\section{f. Menggunakan ekspresi preventing}

- The test items

There is no test item

The Indicator and test item are inappropriate because there is no test item that provided, while the indicator is mengidentifikasi dialog ungkapan persuading pada kumpulan dialog yang disajikan, mengidentifikasi dialog ungkapan encouranging pada kumpulan dialog yang disajikan, mengidentifikasikan dialog ungkapan preventing pada kumpulan dialog yang disajikan, menggunakan ekpresi about asking persuading, menggunakan ekspresi encouraging, menggunakan ekspresi preventing

\section{CONCLUSION AND SUGGESTIONS}

Based on the research finding and discussion,it is concluded that the test item constructed in PPL II reports mostly inappropriate if it is referred to indicators, the appropriateness between test item and indicatorsconstructed in PPL II report of STKIP PGRI Banjarmasin year 2015 is $25 \%$ from the number of evaluations which appropriate with the indicators it is 3 test items and $75 \%$ from the number of evaluations which not appropriate with the indicators it is 9 test items. The inappropriateness test items and indicators mostly caused by there are no test items provided in RPP, for an appropriate RPP developing, the test item should be provided.

Based on the conclusion above, it is suggested that:

1. For lecturer of Language Testing course, he/she has to improve the teaching and learning process till the students understand well how to make an appropriate RPP.

2. The students; the students of teaching practice II must pay attention when they are constructing test item based on the indicators

3. Other researcher; this research can use as valuable information for the next researchers who are interested in conducting research on similar object or other objects.

\section{REFERENCES}

Douglas, H. Brown. 2000. Teaching by Principles An Interactive Approach to Language Pedagogy. Second Edison. San Francisco: California.

Brown, H. Douglass. 2004 Language Assessment: Principles and Classroom Practices. Pearson Education. San Francisco State University.

Departemen Pendidikan Nasional. 2007. Materi Sosialisasi dan Pelatihan Kurikulum Tingkat Satuan Pendidikan (KTSP). Jakarta

Departemen Pendidikan Nasional. 2007. Model Silabus Dan Rencana Pelaksanaan Pembelajaran. Jakarta

Departemen Pendidikan Nasional. 2006. Petunjuk Teknis Pengembangan Silabus Dan Contoh/Model Silabus. Jakarta

Harold S. Madsen. 1983. Techniques in Testing. Oxford University Press. 
Hopkins, Charles D. and Ante, Richard L. 1990. Classroom Measurement and Evaluation. F.E. Peacock Publishers, Inc.

Mulyasa, E. 2006. Kurikulum Tingkat Satuan Pendidikan. Bandung: PT Remaja Rosdakaraya

Muslich, Masnur. 2007. KTSP : Pembelajaran Berbasis Kompetensi dan Kontekstual. Jakarta: PT Bumi Aksara.

Prabowo, Sugeng Listyo. 2006. Perencanaan Pembelajaran. UIN Maliki Press.

Suharsimi Arikunto. 1987. Dasar-dasar Evaluasi Pendidikan. Bina Aksara. 